\title{
PENERAPAN e-BANKING DALAM MENINGKATKAN JASA DAN PELAYANAN PERBANKAN PT.BANK MANDIRI KANTOR CABANG PADANG
}

\author{
Tutri Amelia Putri, Elva Dona \\ Akademi Keuangan dan Perbankan Padang
}

\begin{abstract}
ABSTRAK
Tujuan dari penelitian ini untuk mengetahui penerapan e-Banking dalam meningkatkan jasa dan pelayanan perbankan pada PT.Bank Mandiri Kantor Cabang Padang. Data yang digunakan dalam penelitian ini adalah dengan mewawancarai langsung pihak-pihak yang berkepentingan dalam hal ini adalah perusahaan yang terkait. Adapun teknik pengumpulan data yaitu dengan studi lapangan dan studi kepustakaan dari penelitian dan pembahasan maka dapat diambil kesimpulan bahwa e-Banking meliputi semua transaksi yang terjadi antara perusahaan, organisasi, individu, dan lembaga perbankan mereka, dapat memberikan kenyamanan bagi penggunanya, tanpa harus datang ke bank, tanpa harus mengantri dan bagi pihak bank e-Banking memberikan keuntungan financial.
\end{abstract}

Kata Kunci : e-Banking, Jasa, Pelayanan Perbankan

\section{PENDAHULUAN}

Menyadari semakin ketatnya persaingan yang terjadi di dunia bisnis dimasa ini, menuntut setiap perusahaan untuk lebih serius dan bekerja keras dalam usaha memenangkan persaingan melalui peningkatan kualitas barang dan jasa yang dihasilkan. Untuk dapat menang dalam sebuah persaingan tentunya sebuah perusahaan, haruslah mampu membaca peluang dan memenuhi keinginan yang diharapkan oleh konsumen. (Freddy Rangkuti, 2005). Hal semacam ini bukan hanya terjadi pada sebuah perusahaan manufacture tetapi juga berlaku pada perusahaan-perusahaan yang menyediakan layanan jasa, salah satunya jasa perbankan.

Teknologi merupakan suatu kemajuan bagi kalangan manusia di seluruh dunia. Kehidupan manusia tidak lepas dari peran teknologi yang semakin hari semakin canggih, maju dan makin meringankan pekerjaan manusia. Dalam dunia perbankan misalnya, dengan kemajuan teknologi, efektifitas waktu dapat dipercepat dalam sistem transaksi nasabah dengan nasabah lainnya.

Penggunaan teknologi e-Banking merupakan sebuah terobosan baru dalam dunia perbankan saat ini, dimana dengan menggunakan fasilitas e-Banking, 
para nasabah tidak perlu harus berada di bank dan membuang banyak waktu untuk melakukan sebuah transaksi, karena transaksi bisa dilakukan dimana saja melalui telephone, sms, ATM atau internet. Selain memudahkan bagi para nasabah dalam melakukan transaksi, penggunaan fasilitas e-Banking juga membantu meringankan tugas pihak penyedia layanan jasa perbankan dalam melayani para nasabah. Bagi para konsumen yang tingkat kesibukannya rendah mungkin menggunakan fasilitas e-Banking tidaklah menjadi sebuah keharusan tetapi akan berbeda dengan konsumen yang tingkat kesibukannya lebih tinggi. Para konsumen yang tingkat kesibukanya tinggi menganggap bahwa fasilitas eBanking sangat dibutuhkan dan tergolong penting, karena sangat membantu mereka dalam melakukan suatu transaksi ditengah aktivitas dan kesibukan mereka.

Selain itu transaksi dengan e-Banking juga dapat membantu mengurangi masalah dan hambatan yang ada pada umumnya sering terjadi pada sistim pelayanan manual perbankan seperti banyaknya nasabah yang akan melakukan transaksi karena pada umumnya bank menerapkan sistim antrian berdasarkan nomor urut antrian sehingga dibutuhkan banyak waktu untuk melakukan suatu transaksi. Selain itu masalah lain yang sering terjadi dan menghambat dalam proses transaksi manual adalah sering terganggunya sistem jaringan (Offline) yang menyebabkan pelayanan menjadi lambat bahkan terhenti. Fasilitas-fasilitas e-Banking yang digunakan di PT.Bank Mandiri Kantor Cabang Padang antara lain adalah :

Tabel 1

Fasilitas e-Banking PT. Bank Mandiri Kantor Cabang Padang

\begin{tabular}{|c|c|}
\hline No & Fasilitas-Fasilitas e-Banking \\
\hline 1 & Internet Banking \\
\hline 2 & Phone Banking \\
\hline 3 & Mobile Banking \\
\hline
\end{tabular}

Sumber: PT Bank Mandiri Kantor Cabang Padang.

Berdasarkan latar belakang diatas, adapun rumusan masalah dalam penulisan tugas akhir yaitu Bagaimana Penerapan e-Banking Dalam Mengingkatkan Jasa Dan Pelayanan Perbankan Di PT. Bank Mandiri Kantor Cabang Padang.

\section{TINJAUAN PUSTAKA}

\section{Pengertian Bank}

Secara umum bank diartikan sebagai lembaga keuangan yang kegiatan usahanya adalah menghimpun dana dari masyarakat dan menyalurkan kembali dana tersebut ke masyarakat serta memberikan jasa-jasa bank lainnya.

Menurut undang-undang nomor 10 tahun 1998 yang dimaksud dengan bank adalah badan usaha yang menghimpun dana dari masyarakat dalam bentuk 
simpanan dan menyalurkannya ke masyarakat dalam bentuk kredit dan atau bentuk-bentuk lainnya dalam rangka meningkatkan taraf hidup rakyat banyak.

Dari kedua defenisi tersebut dapat disimpulkan bahwa bank merupakan lembaga keuangan yang kegiatannya adalah:

a. Menghimpun dana (uang) dari masyarakat dalam bentuk simpanan, maksudnya dalam hal ini bank sebagai tempat menyimpanan uang atau berinvestasi bagi masyarakat.

b. Menyalurkan dana kemasyarakat, maksudnya adalah bank memberikan pinjaman (kredit) kepada masyarakat yang mengajukan permohonan.

c. Memberikan jasa-jasa bank lainnya, seperti pengiriman uang (transfer) penagihan surat-surat berharga yang berasal dari dalam kota (clearing), penagihan surat-surat berharga yang berasal dari luar kota dan luar negeri (inkaso), letter of credit (L/C), safe deposit box, bank garansi, bank notes, dan jasa lainnya.

2. Fungsi Bank

Dalam berbagai buku perbankan, suatu bank didefenisikan sebagai lembaga keuangan yang usaha pokoknya adalah menghimpun dana dan menyalurkan kembali dana tersebut ke masyarakat dalam bentuk kredit serta memberikan jasa-jasa dalam lalu lintas pembayaran.

3. Jenis-jenis Bank

Pada dasarnya bank dibagi menjadi tiga yaitu, Bank Sentral, Bank Umum, Bank Perkreditan Rakyat.

a. Bank Sentral

Merupakan bank yang mengatur berbagai kegiatan yang berkaitan dengan dunia perbankan dan dunia di suatu negara. Disetiap negara hanya ada satu bank sentral yang dibantu oleh cabang-cabangnya.

Indonesia memiliki bank sentral yaitu Bank Indonesia yang merupakan bank yang dapat membuat uang kartal baik dala bentuk kertas ataupun logam. Bank Indonesia memiliki tugas-tugas sebagai Bank Sentral Indonesia yaitu:

a) Mengatur peredaran uang di Indonesia.

b) Sebagai tempat penyimpanan terakhir.

c) Mengatur perbankan Indonesia.

d) Mengatur perkreditan.

e) Menjaga stabilitas mata uang.

f) Mengajukan pencetakan / penambahan mata uang rupiah.

b. Bank Umum

Merupakan bank yang melaksanakan kegiatan usaha secara konvensional dan atau berdasarkan prinsip syariah yang dalam kegiatannya memberikan jasa dalam lalu lintas pembayaran. Bank Umum menawarkan berbagai layanan produk dan jasa kepada masyarakat dengan fungsi seperti menghimpun dana secara langsung dari masyarakat dalam berbagai bentuk, memberi kredit pinjaman kepada masyarakat yang membutuhkan, jual beli valuta asing/valas, menjual jasa asuransi, jasa giro, jasa cek, menerima 
penitipan barang berharga dan sebagainya. Yang membedakan Bank Umum dengan Bank Sentral adalah Bank Sentral dapat menerbitkan Uang Kartal sedangkan Bank Umum hanya dapat menerbitkan Uang Giral.

c. Bank Perkreditan Rakyat

Merupakan bank yang melaksanakan kegiatan usaha secara konvensional atau berdasarkan prinsip syariah yang dalam kegiatannya tidak memberikan jasa dalam lalu lintas pembayaran. Serta Bank Perkreditan Rakyat juga merupakan bank penunjang yang memiliki keterbatasan wilayah operasional dan dana yang dimiliki dengan layanan yang terbatas pula seperti memberikan kredit pinjaman dengan jumlah yang terbatas, menerima simpanan masyarakat umum, menyediakan pembiayaan dengan prinsip bagi hasil, penempatan dana dalam sertifikat bank indonesia, deposito berjangka, tabungan atau surat-surat berharga lainnya.

3. Jenis Bank Berdasarkan Kepemilikannya

a.Bank Milik Pemerintah

Bank milik pemerintah adalah bank yang dimana baik akta atau pendirian maupun modalnya dimiliki pemerintah, sehingga seluruh keuntungan bank dimiliki oleh pemerintah pula. Contohnya Bank Rakyat Indonesia (BRI), Bank Mandiri.

b. Bank Milik Swasta Nasional

Bank Swasta Nasional adalah bank yang seluruh atau sebagian besar modalnya dimiliki oleh swasta nasional serta akta pendiriannya didirikan oleh swasta, begitu pula pembagian keuntunganya juga diperuntunkan untuk swasta pula. Contoh Bank Muamalat, Bank Danamon, Bank Niaga.

c. Bank Milik Asing

Bank jenis ini merupakan cabang dari bank yang ada diluar negeri, baik milik swasta asing maupun pemerintah asing. Kepemilikannya dimiliki oleh pihak luar negeri. Contoh City Bank, AMRO, dan lain-lain.

4. Bentuk dan Produk-Produk Bank

Beberapa bentuk produk perbankan berupa pemberian kredit, pemberian jasa pembayaran dan peredaran uang, serta bentuk jasa perbankan lainnya. Untuk penjelasannya sebagai berikut:

a. Pemberian kredit dengan berbagai macam bentuk jaminan atau tanggungan. Misalnya tanggungan efek.

b. Memberi jasa-jasa dalam lalu lintas pembayaran dan peredaran uang yang terdiri dari:

c. Lalu lintas pembayaran dalam negeri seperti transfer, inkaso.

d. Lalu lintas pembayaran luar negeri seperti pembukaan L/C (letter of credit) yaitu surat jaminan bank untuk transaksi ekspor-impor.

e. Jasa- jasa perbankan yang meliputi:

1) Jual-beli cek perjalanan

2) Jual-beli uang kertas

3) Mengeluarkan kartu kredit 
4) Jual beli valuta asing

5) Pembayaran listrik, telepon, pajak,gaji.

6) Menyiapkan kotak pengamanan (safe deposit box)

f. Bentuk-bentuk simpanan di bank

1) Giro adalah simpanan pada bank yang dapat digunakan sebagai alat pembayaran.

2) Deposito berjangka adalah simpanan pada bank yang penarikannya dilakukan pada watu tertentu.

3) Sertifikat deposito adalah deposito berjangka yang bukti simpanannya dapat diperdagangkan.

4) Tabungan adalah simpanan pada bank yang penarikannya hanya dapat dilakukan meurutb syarat-syarat tertentu yang telah disepakati.

\section{METODE PENELITIAN}

Untuk menganalisa data penelitian, penulis menggunakan analisa Deskriptif, terhadap Penerapan e-Banking Dalam Meningkatkan Jasa Dan Pelayanan Perbankan Di PT. Bank Mandiri Kantor Cabang Padang.

\section{HASIL DAN PEMBAHASAN}

Agar penerapan e-banking dalam meningkatkan jasa dan pelayanan nasabah itu meningkat dari tahun ke tahun PT.Bank Mandiri Kantor Cabang Padang menerapkan kegiatan pemasaran yang terencana dan terarah. Untuk melihat tingkat keberhasilan pemasaran yang telah dilakukan suatu bank dapat dilihat dari segi marketing mix.

1. Produk (Product)

Strategi produk merupakan strategi pemasaran lainnya. Yang perlu diperhatikan dalam strategi ini adalah mengembangkan produk baru, hal ini dilakukan karena persaingan antar bank yang semakin ketat disebabkan nasabah sudah cukup kritis dan pandai membanding - bandingkan produk dan jasa bank yang satu dengan yang lainya.

\section{Tabel 2}

Jumlah Pengguna e- Banking dan Nasabah PT. Bank Mandiri Kantor Cabang Padang Tahun 2013-2015

\begin{tabular}{|c|c|c|c|c|}
\hline \multirow{2}{*}{ Tahun } & \multicolumn{2}{|c|}{ Pengguna e- Banking } & \multicolumn{2}{c|}{ Nasabah } \\
\cline { 2 - 5 } & Jumlah & $\begin{array}{c}\text { Perubahan } \\
(\boldsymbol{\%})\end{array}$ & Jumlah & Perubahan (\%) \\
\hline 2013 & 2.175 & $76,22 \%$ & 15.421 & $1686,98 \%$ \\
\hline 2014 & 3.833 & $-7,87 \%$ & 275.571 & $-9,27$ \\
\hline 2015 & 3.531 & $170,15 \%$ & 250.000 & 116,39 \\
\hline
\end{tabular}

Sumber : Data di olah oleh penulis 


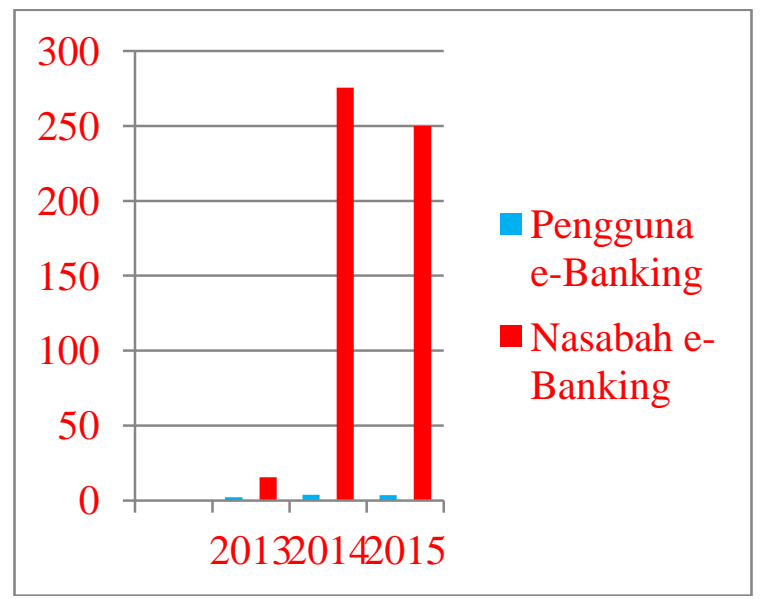

Gambar 1

Jumlah e-Banking dan jumlah nasabah PT.Bank Mandiri Kantor Cabang Padang

Berdasarkan tabel dan diagram di atas 1 perkembangan jumlah pengguna e-banking dari tahun 2013 sampai 2015 mengalami peningkatan. Pada tahun 2013-2014 sebesar Rp. 1,663 atau 76,22\%, kemudian pada tahun 2014-2015 sebesar Rp. 0,302 atau 7,87\% dan begitu juga jumlah nasabah ebanking meningkat dari tahun ke tahun, pada tahun 2013-2014 Rp. 260.089 atau 1686,98\% kemudian pada tahun 2014-2015 RP. 25.571 atau 9,27\%.

Secara umum meningkatnya perkembangan jumlah pengguna ebanking dan jumlah nasabah pada PT.Bank Mandiri Kantor Cabang Padang karena dapat memudahkan nasabah dalam melakukan berbagai transaksi yang ada di bank dan nasabah tidak perlu membuang banyak waktu untuk melakukan sebuah transaksi karena transaksi bisa dilakukan dimana saja.

2. Harga (Price)

Harga adalah sejumlah uang yang dibutuhkan untuk mendapatkan sejumlah kombinasi dari barang beserta pelayananya. Ada beberapa hal yang perlu diperhatian yaitu penetapan tingkat suku bunga, metode penetapan tingkat bunga tabungan dan deposito dan faktor lain yang mempengaruhi tingkat suku bunga.

3. Place (Jaringan Kerja/lokasi)

Dalam menentukan areal distribusinya PT. Bank Mandiri Kantor Cabang Padang menetapkan suatu lokasi di pusat kota Padang yang mudah dijangkau oleh nasabah/pasarnya dekat dengan nasabah sehingga dapat menghubungkan nasabah dengan cepat.

4. Promosi (Promotion)

Dalam menghimpun dan menyalurkan dana PT. Bank Mandiri Kantor Cabang Padang melakukan kebijaksanaan promosi dengan cara sebagai berikut: 
a) Periklanan

Kebijaksanaan periklanan yang dilakukan melalaui brosur, spanduk, radio dan papan reklame. Brosur-brosur yang mengenai aktivitas jasa yang ditawarkan disebarkan kepada masyarakat, pelajar, instansi yang ada di tengah-tengah masyarakat guna menrik keinginan mereka untuk menggunakan fasilitas yang disediakan oleh PT. Bank Mandiri Kantor Cabang Padang.

b) Promosi Penjualan

Kebijaksanaan penjualan dilakukan dengan cara penarikan undian berhadiah untuk masyarakat yang menggunakan fasilitas e- Banking pada PT. Bank Mandiri Kantor Cabang Padang dengan memberikan hadiah hadiah.

c) Personal Selling

Kebijaksanaan personal selling dilakukan dengan cara menugaskan karyawan untuk langsung mempromosikan produk fasilitas e- banking kepada masyarakat seperti Pengusaha Menengah Atas, Kantor Pemerintahan, Perguruan Tinggi Negeri dan Perguruan Tinggi Swasta.

5. People (Orang)

Untuk mencapai kualitas yang terbaik, petugas atau pegawai bank harus diberi latihan, sehingga ia menyadari betapa pentingnya mereka, sehingga dapat memberikan kepuasan maksimum kepada nasabah.

6. Proces

Proses merupakan gabungan semua aktivitas, umumnya terdiri dari prosedur, jadwal, mekanisme, aktivitas produk dan jasa bank yang disampaikan kepada nasabah, prosedur pelaksanaan, mekamisme kerja.

Dalam proses ini PT. Bank Mandiri Kantor Cabang Padang membuat prosedur dan mekanisme layanan secara sederhana dan tidak berbelit - belit sehingga nasabah tidak membutuhkan waktu yang panjang dalam melalui layanan tersebut.

\section{KESIMPULAN}

Berdasarkan uraian yang telah di kemukakan pada bab-bab terdahulu, maka penulis dapat menyampaikan beberapa kesimpulan mengenai Penerapan Internet Banking Dalam Meningkatkan Jasa Dan Pelayanan Perbankan Di Bank Mandiri Kantor Cabang Padang yaitu sebagai berikut:

1. e-banking adalah istilah yang menggambarkan semua transaksi yang terjadi antara perusahaan, organisasi, individu, dan lembaga perbankan mereka.

2. e-Banking meliputi sistem yang memungkinkan nasabah bank, baik individu ataupun bisnis, untuk mengakses rekening, melakukan transaksi bisnis, atau mendapatkan informasi produk dan jasa bank melalui jaringan pribadi atau publik, termasuk internet.

3. Penerapan e-Banking bagi nasabah yaitu memberikan kenyamanan bagi peggunanya, tanpa harus datang ke bank, tanpa harus mengantri dan bagi 
pihak bank e-Banking memberikan keuntungan financial maupun citra di mata nasabahnya.

\section{DAFTAR PUSTAKA}

Kasmir.2010 Dasar-Dasar Perbankan.Jakarta:Raja Grafindo

Undang-Undang Nomor 10 Tahun 1998 Tentang Perbankan, Penerbit Sinar Grafika, Jakarta, 1999.

Kotler,Philip,1997,Manajemen Pemasaran”.Analisis perencanaan,implementasi dan pengendalian.buku dua,salemba empat prentiochall,Jakarta.

Lupiyoadi, Rambat, Manajemen Pemasaran Jasa : Teori dan Praktek, Jakarta, PT Salemba Empat, 2004

Marlius, D. (2017). Keputusan Pembelian Berdasarkan Faktor Psikologis Dan Bauran Pemasaran Pada PT. Intercom Mobilindo Padang. Jurnal Pundi. Volume 1. No. 1. Hal. 57-66. https://doi.org/10.31575/jp.v1i1.9

Marlius, D. (2016). Pengaruh Bauran Pemasaran Jasa Terhadap Minat Nasabah Dalam Menabung Pada Bank Nagari Cabang Muaralabuh. https://doi.org/10.31227/osf.io/vdqgx

Philip Kotler dan Armstrong,1999,Prinsip-Prinsip pemasaran edisi kedelapan jilid satu,jakarta

Safitri, R. N., \& Marlius, D. (2017). Penerapan E-Banking Dalam Meningkatkan Jasa Dan Layanan Perbankan Di PT. Bank Rakyat Indonesia Cabang Padang. https://doi.org/10.31227/osf.io/gkv8t

Sugiyono dan Eri Wibowo. 2004. Statistika untuk Penelitian dan Aplikasinya dengan SPSS 10.0 for windows. Cetakan Keempat : November. Bandung : Alfabeta

Tjibtono, Fandy, Prespektif Manajemen Dan Pemasaran Kontenporer, Edisi I, Penerbit Andi. Yokyakarta, 2000.

Tjiptono, Fandi, Strategi Pemasaran, Edisi Ketiga, Jogjakarta, Andi Offset, 1997

Umar, Husain, Riset Pemasaran dan Perilaku Konsumen, Jakarta, PT Gramedia Pustaka Utama, 2000 
Umar,Husein,2003,Metode Riset Perilaku Konsumen Jasa, Ghalia Indonesia,jakarta

http://dalinta.blogspot.co.id/2012/10e-banking.html

http://blog.pasca.gunadarma.ac.id/2012/11/20/penerapan-e-banking-dan-mbanking/

www.bankmandiri.co.id 